Open Journal System

Volume 1 no 12020

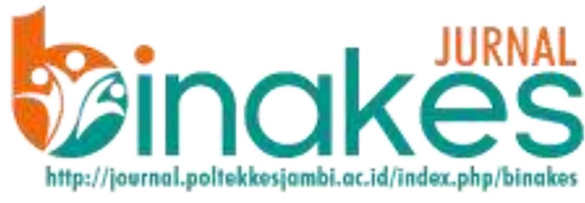

\title{
VISUALISASI PLAK DENGAN SUMBA: METODE PRAKTIS MENINGKATKAN KETERAMPILAN MENYIKAT GIGI
}

\author{
Karin Tika Fitria ${ }^{1}$, Naning Nur Handayatun ${ }^{1}$ \\ ${ }^{1}$ Jurusan Keperawatan Gigi Poltekkes Kemenkes Jambi
}

\section{KONTAK PENULIS}

karin.tikafitria@gmail.com

DOI:

https://doi.org/10.35910/binake s.v1i1.417

Kata Kunci:

Sumba; plak; menyikat gigi

\section{ABSTRAK}

Latar Belakang: Eliminasi plak yang merupakan etiologi utama penyakit gigi karies dan periodontal menjadi kunci pencegahan penyakit gigi dan mulut. Penggunaan sumba yang sebelumnya telah terbukti dapat mendeteksi plak merupakan bahan yang mudah dijangkau oleh berbagai kalangan masyarakat. Kegiatan Pengabdian masyarakat ini bertujuan untuk meningkatkan keterampilan menyikat gigi dengan penggunaan sumba sebagai bahan untuk visualisasi plak gigi

Metode: Kegiatan pengabdian masyarakat dilakukan pada murid kelas 5 SDN 33/IV Penyengat Olak Kabupaten Muaro Jambi. Kegiatan diawali dengan penyuluhan kesehatan gigi dan mulut, demonstrasi dan praktik pembuatan disclosing solution atau plak detector dari sumba. Bimbingan menyikat gigi secara personal serta lomba gigi bersih sebagai positive reinforcement

Hasil: Peningkatan pengetahuan sebanyak $100 \%$ pada anak yang diberikan penyuluhan dan demonstrasi penggunaan sumba sebagai plak detector. Perbedaan bermakna skor plak $(\mathrm{p}=0,000)$ terlihat antrara sebelum dan sesudah penyuluhan, demonstrasi, praktik penggunaan sumba dan bimbingan menyikat gigi

Kesimpulan: Terjadi peningkatan pengetahuan dan peningkatan nilai skor plak setelah pemberian penyuluhan, demonstrasi, praktik pengunaan sumba serta bimbingan menyikat gigi pada anak

\section{Keywords:}

sumba; dental plaque; tooth brushing

\section{ABSTRACT}

Introduction: Elimination of plaque, as the main etiology of caries and periodontal disease, is the key to preventing dental and oral diseases. The use of sumba, which has previously been proven to be able to detect plaque, is a material that is easily accessible by various groups of people. This community service activity aims to improve tooth brushing skills by using sumba to visualisize the dental plaque.

Methods: Community service activities were carried out on 5th grade students of SDN 33 / IV Penyengat Olak, Muaro Jambi Regency. The activity began with dental and oral bealth education, demonstration and practice of making disclosing solutions or plaque detectors from Sumba. Guidance on personal brushing and clean teeth competitions as positive reinforcement

Results: $100 \%$ increase in knowledge in children who were given counseling and demonstrations on the use of Sumba to visualize the dental plaque. Significant differences in plaque scores $(p=0.000$ were seen between before and after counseling, demonstrations, practice of using Sumba and guidance on brushing teeth.

Conclusion: There was an increase in knowledge and an increase in the value of plaque scores after counseling, demonstrations, the practice of using Sumba and guidance on brushing teeth in children. 


\section{PENDAHULUAN}

Penyakit gigi dan mulut merupakan penyakit masyarakat yang dapat menyerang semua golongan umur yang bersifat progresif dan akumulatif. Penyakit gigi dan mulut yang terbanyak dialami masyarakat di Indonesia adalah karies gigi dan penyakit periodontal(Banjar and Alshammari, 2014; Frencken et al., 2017). Berdasarkan Riset Kesehatan Dasar tahun 2018 ditemukan masalah kesehatan gigi dan mulut di Indonesia sebanyak $57,6 \%$ dimana kelompok umur 5-9 tahun sebesar 92,6\% dan kelompok umur 10-14 tahun sebesar $73,4 \%$. Penyakit periodontal ditemukan sebanyak $73,1 \%$ dan karies gigi sebanyak $88,8 \%$. Di Provinsi Jambi terdapat sekitar $37,7 \%$ penduduk yang mempunyai masalah kesehatan gigi dan mulut. Perilaku menyikat gigi dengan benar pada umur $>3$ tahun ditemukan paling rendah di Propinsi Jambi (Kementerian Kesehatan RI, 2018).

Plak gigi sangat berperan pada terjadinya dua penyakit gigi dan mulut yaitu karies dan radang periodonsium. Oleh sebab itu pada pencegahan kedua penyakit ini penghilangan plak adalah penting. Plak dapat dikontrol dengan penggunaan alat-alat mekanis dan kimiawi(Ion and Chetruş, 2013). Dengan pembersihan mekanis dimaksudkan penghilangan plak oleh tindakan psikomotoris pasien. Ini berarti pengambilan plak secara teratur setiap kali terbentuk pada gigi dan gusi dengan bantuan alat-alat khusus seperti sikat gigi, tusuk gigi dan benang gigi(Rane et al., 2017).

Karies merupakan suatu penyakit jaringan keras gigi, yaitu email, dentin dan sementum, yang disebabkan oleh aktivitas suatu jasad renik dalam suatu karbo hidrat yang dapat diragikan. Secara teori ada tiga cara dalam mencegah karies yaitu dengan menghilangkan substrat karbohidrat, meningkatkan ketahanan gigi dan menghilangkan plak bakteri(Hausen, Jossing and Fejerskov, 2015). Plak yang melekat pada gigi dapat dihilangkan dengan cara menyikat gigi serta merupakan salah satu cara yang paling efektif untuk memelihara kebersihan gigi dan mulut(Marsh, Moter and Devine, 2011).
Secara klinis, plak gigi merupakan lapisan bakteri yang lunak, tidak terkalsifikasi, menumpuk dan melekat pada gigi geligi dan objek lain di dalam mulut, misalnya restorasi, geligi tiruan, dan kalkulus. Dalam bentuk lapisan tipis plak umumnya tidak terlihat dan hanya dapat terlihat dengan bantuan bahan disclosing (Fasoulas et al., 2019). Karakteristik dari plak antara lain mempunyai perlekatan erat dengan gigi dan tidak dapat dihilangkan dengan kumurkumur atau irigasi tetapi dapat dihilangkan dengan penyikatan (Valm, 2019).

Ada banyak teknik penyikatan gigi yang diperkenalkan dewasa ini, tetapi metode penyikatan yang dapat memenuhi persyaratan ideal hanya ada beberapa saja yaitu teknik penyikatan harus dapat membersihkan semua permukaan gigi, khususnya daerah leher gingiva dan regio interdental. Gerakan sikat tidak boleh melukai jaringan lunak maupun jaringan keras. Teknik penyikatan harus sederhana dan mudah dipelajari. Metode tersusun dengan baik sehingga setiap bagian gigi geligi dapat disikat bergantian dan tidak ada daerah yang terlewatkan. Teknik penyikatan gigi dapat diperlihatkan dengan menggunakan model rahang atau langsung di dalam mulut pasien.

Karena plak tembus pandang dan warnanya sama dengan warna gigi, maka supaya terlihat plak tersebut harus diberi warna terlebih dulu. Zat pewarna plak ini disebut Disclosing Solution. Zat pewarna plak dapat digunakan untuk menunjukkan adanya plak kepada pasien dan bermanfaat sebagai alat penyuluhan dan pemberi motivasi yang baik(Fasoulas et al., 2019) .

Sebelumnya yodium, pewarna makanan, Bismarck brown, mercurochrome dan basic fuscin digunakan sebagai zat pewarna plak. Namun dewasa ini, eritrosin adalah zat yang paling sering dipakai. Zat ini tersedia dalam bentuk cairan atau tablet kunyah. Dengan eritrosin (bahan pewarna merah untuk mewarnai plak bakteri), pelikel terlihat bewarna merah muda terang. Penggunaan fuksin, larutan yodium dan merkurokrom dapat merugikan. Fuksin mewarnai plak dan selaput lendir selama 
beberapa jam; yodium mempunyai rasa yang tidak enak dan sukar dihilangkan.

Cairan, tablet, dan kapsul yang berisi eritrosin atau pewarna sayuran bisa digunakan untuk mewarnai plak dan disebut bahan penyingkap(Perry, Takei and Do, 2018).

Penggunaan eritrosin diperkenalkan oleh Arnim yang dipublikasikan pada tahun 1963 karena menurutnya bahan pewarna plak harus menampakkan plak dengan warna merah yang mengesankan. Deposit biofilm pada bagian proksimal, oklusal dan permukaan lain yang sulit dijangkau seringkali tidak terdeteksi. Kemudian muncul publikasi yang mengumumkan zat pewarna lain. Mereka berpendapat bahwa plak harus ditampakkan untuk dapat "menegur" orang-orang. Warna merah tidak memberikan kontras kuat dengan gingiva, sehingga beberapa pasien mengeluh tidak mampu menghilangkan plak dengan baik di rumah. Oleh karena itu digunakan zat pewarna yang disusun dari warna merah dan hijau. Zat pewarna ini mempunyai keuntungan bahwa pelikel dan plak baru yang tipis menjadi merah, tetapi plak lama yang tebal menjadi biru. Dengan ini dapat dibedakan umur plak akan tetapi di dalam praktek perbedaan ini sukar dibuat(Datta, 2017).

Karena plak tembus pandang dan warnanya sama dengan warna gigi, maka supaya terlihat plak tersebut harus diberi warna terlebih dulu. Zat pewarna plak ini disebut Disclosing Solution. Zat pewarna plak dapat digunakan untuk menunjukkan adanya plak kepada pasien dan bermanfaat sebagai alat penyuluhan dan pemberi motivasi yang baik. Seseorang harus dapat mengevaluasi sendiri daerah mana yang perlu lebih cermat dilakukan penyikatan gigi(Sueishi et al., 2017)

Pada awalnya yodium, pewarna makanan, Bismarck brown, mercurochrome dan basic fuscin digunakan sebagai zat pewarna plak. Namun dewasa ini, eritrosin adalah zat yang paling sering dipakai. Zat ini tersedia dalam bentuk cairan atau tablet kunyah. Dengan eritrosin (bahan pewarna merah untuk mewarnai plak bakteri), pelikel terlihat bewarna merah muda terang. Penggunaan fuksin, larutan yodium dan merkurokrom dapat merugikan. Fuksin mewarnai plak dan selaput lendir selama beberapa jam; yodium mempunyai rasa yang tidak enak dan sukar dihilangkan(PF, 2005).

Larutan disklosing sebagai bahan kontrol plak sulit ditemukan di pasaran khususnya di Kota Jambi, karena hanya tersedia di toko bahan kedokteran gigi di kota besar seperti Jakarta dan Yogyakarta. Harga larutan ini cukup mahal, padahal sebaiknya bahan ini ada pada setiap rumah tangga sebagai alat bantu untuk menjaga kebersihan gigi dan mulut.

Menurut Peraturan Menteri Kesehatan Republik Indonesia Nomor : 722/Menkes/Per/IX/88 tentang Bahan Tambahan Makanan, pewarna adalah bahan tambahan makanan yang dapat memperbaiki atau memberi warna pada makanan. Sumba kue dalam bentuk cair atau bubuk adalah salah satu pewarna makanan yang bersifat sintetis dan telah mendapatkan sertifikat kelayakan konsumsi dari Kementerian Kesehatan Direktorat Jenderal Pengawasan Obat dan Makanan bagian proyek Pengembangan dan Pembinaan Obat dan Perbekalan Farmasi 1989/1990, sehingga aman digunakan dan mudah diperoleh karena diproduksi secara massal, serta harganya relatif murah. Larutan sumba adalah pewarna makanan yang umumnya digunakan untuk mewarnai makanan seperti kue yang terbuat dari karbohidrat (tepung beras, tepung terigu, pati dan sebagainya). Salah satu komposisi plak adalah karbohidrat (13-18\%), maka dapat dikatakan bahwa larutan sumba dapat mewarnai karbohidrat dalam plak. Menurut Yunari S. (cit. Anggraeni,dkk, 2000), penggunaan pewarna makanan (warna merah dan hijau) sebagai pendeteksi plak di rumah dapat digunakan.

Hasil penelitian Kayo, Handayatun dan Mudehir (2012), larutan disklosing dapat diganti dengan sumba yang harganya lebih murah dan dapat ditemukan di Jambi.

Salah satu resolusi dari The 60th World Health Assembly (WHA) oleh WHO tahun 2007 adalah mengembangkan dan mengimplementasikan promosi kesehatan gigi dan mulut serta pencegahan penyakit gigi dan mulut sebagai bagian dari kegiatan promosi kesehatan di sekolah dengan fokus 
pada PHBS dan praktik perawatan diri sendiri di sekolah, yaitu dengan pelaksanaan sikat gigi setiap hari di sekolah (Kemenkes RI, 2012 )

Karies gigi pada anak masih sering diabaikan orang tua karena gigi masih akan diganti dengan gigi permanen. Orang tua sering kurang perhatian bahwa pada murid usia 6-7 sudah ada gigi permanen yaitu molar satu yang sudah tumbuh. Prevalensi karies gigi susu pada murid SD kelas 1,2,3 disekolah sekolah sekitar FKG Unpad sebesar 99,9\% dan def 10,2 (Sufiawati, dkk., 2002). Politeknik Kesehatan Jambi mempunyai tanggung jawab untuk ikut serta dalam membina kesehatan gigi dan mulut disekitar wilayah kerjanya. Kegiatan tersebut berupa pengabdian masyarakat oleh dosen.

Sekolah Dasar 33/IX Penyengat Olak berada di Kabupaten Muaro Jambi. Sekolah tersebut terletak di pinggir jalan raya, jarak ke Puskesmas Penyengat Olak kurang lebih $2 \mathrm{~km}$. Orang tua murid di sekolah tersebut sangat heterogen, ada yang berprofesi sebagai pegawai pemerintah, guru, karyawan swasta dan sebagian besar bekerja sebagai buruh, asisten rumah tangga, maupun tukang cuci. Program UKGS di sekolah tersebut dilaksanakan oleh tenaga kesehatan gigi dari Puskesmas Penyengat Olak. Keterbatasan dana dan petugas menyebabkan pemeriksaan kesehatan gigi dan penyuluhan hanya dilaksanakan pada murid kelas 1(satu). Pelayanan penumpatan gigi yang berlubang tidak tersedia di Puskesmas sehingga pencegahan terjadinya gigi berlubang merupakan pilihan tindakan terpenting untuk mengurangi terjadinya karies gigi.

Murid kelas 5 (lima) SD 33/IX Penyengat Olak banyak yang mengeluh sakit gigi dan beberapa tidak bersekolah karena keluhan tersebut. Prevalensi karies gigi mencapai 99\%. Karies tersebut tidak hanya mengenai gigi susu namun juga gigi permanen. Adanya karies menunjukkan cara membersihkan gigi yang belum maksimal. Sisa makanan yang tidak dibersihkan merupakan sumber makanan bakteri dalam plak sehingga nantinya hasil fermetasinya akan menghasilkan asam yang dapat melarutkan email gigi yang menjadi awal terbentuknya karies. Murid kelas 5 SD 33/IV Muaro Jambi menyatakan bahwa banyak yang mengeluh sakit gigi karena gigi berlubang. Gigi yang berlubang disebabkan oleh cara pembersihan gigi yang belum maksimal.

Pengabdian masyarakat ini bertujuan untuk meningkatkan keterampilan menyikat gigi pada murid kelas 5 SDN 33/IV Penyengat Olak Kabupaten Muaro Jambi.

\section{METODE}

Pelaksanaan kegiatan visualisasi plak dengan sumba dilakukan pada murid kelas 5 (lima) SDN 33/IV Penyengat Olak Kabupaten Muaro Jambi. Sebelum kegiatan, koordinasi dilakukan terlebih dahulu pada pihak Puskesmas, Dinas Pendidikan serta pihak sekolah yang terkait.

Murid kelas 5 belum pernah secara langsung diberikan penyuluhan kesehatan gigi dan mulut oleh tenaga kesehatan gigi sehingga perlu diberikan penyuluhan agar mereka mengerti bagaimana menjaga kebersihan dan kesehatan gigi dan mulut dan pentingnya pemeriksaan kesehatan gigi dan mulut.

Kegiatan diawali dengan pemeriksaan plak gigi kemudian dilanjutkan dengan intervensi berupa penyuluhan kesehatan gigi mulut serta demonstrasi pembuatan disclosing solution dari sumba, serta praktik pengolesan disclosing solution pada seluruh permukaan gigi. Kemudian siswa dibimbing menyikat gigi secara personal lalu dilakukan pemeriksaan plak setelah penyikatan gigi. Kegiatan dilakukan 3 kali dengan interval 2 minggu. Sebagai reinforcement pada pemeriksaan terakhir diberikan reward pada anak yang berhasil memiliki kebersihan plak paling baik.

\section{HASIL}

Hasil kegiatan pengabdian masyarakat pada siswa kelas V SDN 33/IV Penyengat Olak Kabupaten Muaro Jambi berupa visualisasi plak menggunakan sumba untuk 
melatih anak membersihkan plak gigi ditampilkan pada tabel 1.

Tabel 1. Pengetahuan anak setelah diberikan penyuluhan mengenai penggunaan disclosing solution

\section{Sebelum Setelah Intervensi Intervensi $p$-value}

\begin{tabular}{lccccc} 
& $\mathrm{n}$ & $\%$ & $\mathrm{n}$ & $\%$ & \\
\hline Tahu & 0 & 0 & 21 & 100 & \multirow{2}{*}{0,000} \\
\cline { 2 - 5 } Tidak & 21 & 100 & 0 & 0 & \\
\hline Total & 21 & 100 & 21 & 100 & \\
\hline
\end{tabular}

Dari tabel 1 dapat dilihat bahwa pengetahuan seluruh responden meningkat setelah pemberian intervensi berupa penyuluhan mengenai penggunaan disclosing solution. Sebelumnya responden tidak mengetahui sama sekali mengenai bahan yang dapat mendeteksi plak gigi sehingga anak hanya menyikat gigi tanpa memahami tujuan penyikatan gigi. Setalh diberikan pengetahuan mengenai penggunaan disclosing solution, anak anak dapat melihat plak yang tadinya tidak terlihat di permukaan gigi. Kemudian, dengan terlihatnya plak gigi maka anak juga dapat memiliki tolok ukur apakah penyikatan giginya sudah benar atau tidak, karena daerah yang belum tersikat dengan baik akan tetap tertinggal zat warna dari disclosing solution.

Data pemeriksaan plak skor yang dikumpulkan menunjukkan distribusi normal $(p>0,05)$ sehingga selanjutnya untuk melihat perbedaan skor plak sebelum dan sesudah intervensi digunakan uji beda $t$ test berpasangan yang hasilnya dapat dilihat pada tabel 2 .

Tabel 2 menunjukkan bahwa setelah diberikan intervensi berupa penyuluhan cara penggunaan disclosing solution pada minggu pertama, dan anjuran untuk dipraktikkan di rumah, maka pada pemeriksaan berikutnya, pemeriksaan skor plak sebelum sikat gigi menunjukkan hasil yang lebih rendah secara signifikan ( $p$ value 0,000$)$.

Setelah menyikat gigi pada pertemuan kedua, hasilnya juga menunjukkan skor plak yang menurun secara signifikan dibandingkan sebelum inervensi pada pertemuan sebelumnya ( $p$ value 0,000 )
Tabel 2. Perbedaan skor plak sebelum dan sesudah menyikat gigi yang diperiksa sebelum dan sesudah intervensi penggunaan disclosing solution

\begin{tabular}{|c|c|c|c|}
\hline & $\mathbf{n}$ & $\begin{array}{c}\text { Rerata } \\
\text { skor } \\
\text { plak }\end{array}$ & $p$ value \\
\hline \multicolumn{4}{|c|}{ Sebelum menyikat Gigi } \\
\hline $\begin{array}{l}\text { Sebelum } \\
\text { Intervensi }\end{array}$ & 21 & 2,64 & \multirow{2}{*}{0,000} \\
\hline $\begin{array}{l}\text { Sesudah } \\
\text { Intervensi }\end{array}$ & 21 & 2,07 & \\
\hline \multicolumn{4}{|c|}{ Setelah menyikat Gigi } \\
\hline $\begin{array}{l}\text { Sebelum } \\
\text { Intervensi }\end{array}$ & 21 & 2,09 & \multirow{2}{*}{0,000} \\
\hline $\begin{array}{l}\text { Sesudah } \\
\text { Intervensi }\end{array}$ & 21 & 0,50 & \\
\hline
\end{tabular}

\section{PEMBAHASAN}

Kebersihan gigi dan mulut Murid SD 33/IX Penyengat Olak Kabupaten Muaro saat pemeriksaan masih rendah, terlihat dari skor plak pada tabel 2 yaitu sebesar 2,67, serta berdasarkan hasil wawancara responden sebagian besar tidak menyikat gigi setelah sarapan pagi atau bahkan tidak menyikat gigi pada pagi hari.

Menyikat gigi sebaiknya 2 kali sehari setelah sarapan dan sebelum tidur malam(Weijden et al., 2015). Penelitian terdahulu menunjukkan adanya frekuensi menyikat gigi dengan kebersihan rongga mulut yang dilakukan pada siswa sekolah dasar dimana siswa yang menyikat gigi 3-4 kali sehari menunjukkan kebersihan rongga mulut yang lebih baik(Jumriani, 2018). Namun yang paling penting adalah bukanlah teknik menyikat gigi, jenis bulu sikat gigi yang digunakan, namun pembersihan menyeluruh lapisan plak gigi atau biofilm yang berisi bakteri yang menempel pada permukaan gigi dan gusi(Weijden et al., 2015).

Plak yang tidak berwarna sangat sulit dideteksi dengan mata tanpa bantuan cairan berwarna karena plak merupakan bahan yang dapat menyerap warna karena adanya kandungan pelikel dan deposit bakteri di dalam plak(Sueishi et al., 2017). 
Anak juga jajan sebelum belajar di kelas, hal ini mengakibat kan terjadinya penumpukan plak. Hasil Riskesdas untuk propinsi Jambi dalam hal menyikat gigi ternyata bari $1 \%$ yang benar(Kementerian Kesehatan RI, 2018).

Kebersihan gigi dan mulut berkaitan dengan kejadian karies pada anak, ternyata di kelas tersebut prevalensi karies mencapai $76 \%$. Keadaan ini lebih tinggi jika dibandingkan dengan hasil Riskesdas 2018 dimana secara nasional hanya 41,4\% anak berumur 10-14 tahun yang bermasalah dengan kesehatan giginya dan untuk Propinsi Jambi 37,7\% (Kementerian Kesehatan RI, 2018).

Hasil pemeriksaan yang menunjukkan skor plak yang masih buruk pada sebagian besar siswa mungkin disebabkan partisipasi orang tua murid dalam perawatan gigi anak masih rendah karena anak usia sekolah dasar masih sangat bergantung dengan orang tuanya. Pada masa tumbuh kembang anak, peran aktif orang tua sangat penting untuk membentuk perilaku pemeliharaan kesehatan gigi yang baik bagi anak. Bimbingan orang tua dalam penyikatan gigi dapat membantu mencegah timbulnya penyakit gigi dan mulut pada anak sejak dini(Ngatemi and Purnama, 2020)

$$
\begin{gathered}
\text { Pengulangan dan penguatan } \\
\text { merupakan faktor penting dalam }
\end{gathered}
$$
membentuk perilaku terutama pada anak anak. Dengan dorongan positif atas perilaku yang baik maka akan meningkatkan kemungkinan terjadinya perilaku yang baik kembali di masa yang akan dating, sementara pengulangan akan memperkuat perilaku yang baik(Haleem et al., 2016). Keterlibatan orang tua amat penting karena merekalah yang harus memberi penguatan segera setelah menyikat gigi. Frekuensi pemberian penguatan harus dikurangi dengan berjalannya waktu, khususnya setelah target tingkah laku tercapai, dimana kebiasaan menggosok gigi menjadi suatu rutinitas(Boustedt et al., 2020).

Pada pemeriksaan awal, ketrampilan menyikat gigi anak juga masih memprihatinkan, seperti terlihat pada tabel 3 dimana hasil menyikat gigi sebelum intervensi masih banyak plak yang tertinggal setelah menyikat gigi namun setelah intervensi mereka menyikat gigi dengan cukup bersih meskipun masih tersisa skor 3 untuk masing masing anak. Terdapat perbedaan hasil menyikat gig yang signifikat antara sebelum dan setelah kegaiatan. Penggunaan metode tell, show, do ternayata sangat efektif untuk meningkatkan ketrampilan anak dalam menyikat gigi(Lewis, 2020).

Teknik tell show do dilakukan dengan menceritakan prawatan yang akan dilakukan, memperlihatkan padanya beberapa bagian perawatan dan bagaimana itu akan dikerjakannya.. Teknik ini digunakan secara rutin untuk tindakan profilaksis. Setelah itu anak selalu diberikan penguatan (reinforcement) berupa pujian atau bentuk apresiasi lainnya untuk menguatkan perilaku baik yang telah dilakukannya atau dalam hal ini teknik menyikat gigi yang sudah benar sehingga nilai skor plaknya menjadi 0 sesuai yang diharapkan. Hal ini akan Membuat anak mengulai perilaku baik ini ketika menyikat gigi sendiri di rumah(Haleem et al., 2016).

Penggunaan disclosing solution dari sumba sebelum menyikat gigi memotivasi anak untuk menyikat gigi sampai warna merah dari sumba hilang. Pemanfaatan sumba kue sebagai alat bantu menyikat gigi merupakan tindakan yang sangat bermanfaat untuk menjaga kebersihan gigi dan mulut dengan biaya yag sangat murah dan cara yang sederhana dan bahan yang mudah didapat.

Visualisasi plak dengan sumba sebagai pengganti disclosing solution paten yang masih sulit diperoleh di kota Jambi serta harganya yang sulit dijangkau masyarakat luas sangat bermanfaat untuk membantu anak dalam mengidentifikasi bagian gigi mana saja yang perlu perhatian khusus dalam penyikatan gigi sehingga skor plak setelah menyikat gigi yang diharapkan adalah 0 atau bersih dari semua plak gigi di setiap permumkaan giginya.

Oleh karena itu kegiatan ini perlu disosialisasikan kepada guru dan orang tua murid. Jika pengolesan sumba sebelum menyikat gigi diulang beberapa kali maka anak akan terbiasa dengan menyikat gigi yang benar. 


\section{KESIMPULAN}

Dari hasil pengabdian masyarakat pada murid kelas IV murid SD 33/IX Penyengat Olak Kabupaten Muaro Jambi diperoleh kesimpulan adanya terdapat peningkatan ketrampilan menyikat gigi yang bermakna $(\mathrm{p}<0,05)$ pada murid kelas IV SD 33/IX Penyengat Olak Kabupaten Muaro setelah dilakukan promosi kesehatan gigi dengan penyuluhan dan penggunaan disclosing solution dari sumba.

Berdasarkan penelitian ini disarankan bahwa perlu punyuluhan pada orang tua murid tentang perawatan gigi anak serta perlunya pihak sekolah turut memantau keadaan kesehatan gigi muridnya terutama anak-anak yang direkomendasikan untuk segera dilakukan perawatan.

\section{DAFTAR PUSTAKA}

Banjar, W. and Alshammari, M. H. (2014) 'Genetic factors in pathogenesis of chronic periodontitis', Journal of Taibah University Medical Sciences, 9(3), pp. 245-247. doi: 10.1016/j.jtumed.2014.04.003.

Boustedt, K. et al. (2020) 'Tooth brushing habits and prevalence of early childhood caries: a prospective cohort study', European Archives of Paediatric Dentistry. doi: 10.1007/s40368019-00463-3.

Datta, D. D. (2017) 'Disclosing Solutions Used in Dentistry', World Journal of Pharmaceutical Research, (September), pp. 1648-1656. doi: 10.20959/wjpr20176-8727.

Fasoulas, A. et al. (2019) 'Detection of dental plaque with disclosing agents in the context of preventive oral hygiene training programs', Heliyon, 5(7), p. e02064. doi: 10.1016/j.heliyon.2019.e02064.

Frencken, J. E. et al. (2017) 'Global epidemiology of dental caries and severe periodontitis - a comprehensive review', Journal of Clinical Periodontology, 44, pp. S94-S105.

Haleem, A. et al. (2016) 'The role of repetition and reinforcement in school-based oral health education-a cluster randomized controlled trial Health behavior, health promotion and society', BMC Public Health, 16(1). doi: 10.1186/s12889-015-2676-3.

Hausen, H., Jossing, M. and Fejerskov, 0. (2015)
'Caries control in low-caries populations', in Fejerskov, O., Nyvad, B., and Kidd, E. (eds) Dental Caries: The Disease and Its Clinical Management. 3rd edn. Oxford: Wiley Blackwell, pp. 439-448.

Ion, I. R. and Chetruş, V. (2013) 'Dental PlaqueClassification,Formation, and

Identification', International Journal of Medical Dentistry, 3(2), pp. 139-144.

Jumriani (2018) 'Hubungan Frekuensi Menyikat Gigi dengan Tingkat Kebersihan Gigi dan Mulut pada Siswa SD Inpres Btn IKIP I Kota Makassar', Media Kesehatan Gigi, 17(2), pp. 46-49. Available at: http://www.journal.poltekkes-

mks.ac.id/ojs2/index.php/mediagigi/articl e/view/706 (Accessed: 8 March 2021).

Kementerian Kesehatan RI (2018) Laporan Riskesdas 2018, Riskesdas 2018. doi: 10.1017/CBO9781107415324.004.

Lewis, C. (2020) 'Child Behaviour Management: Non-Pharmacological Strategies', Dental Health, 59(5), pp. 33-36. Available at: http://www.sdcep.org.uk/wpcontent/uploads/2018/05/SDCEP(Accessed: 8 March 2021).

Marsh, P. D., Moter, A. and Devine, D. A. (2011) 'Dental plaque biofilms: Communities, conflict and control', Periodontology 2000, 55(1), pp. 16-35. doi: 10.1111/j.16000757.2009.00339.x.

Ngatemi and Purnama, T. (2020) 'Dental Health Handbook as Parents Monitoring in the Formation of Independence for Brushing Teeth in Early Childhood', Indian Journal of Public Health Research \& Development, 11(1), p. 766.

Perry, D. A., Takei, H. H. and Do, J. H. (2018) 'Plaque Biofilm Control for the Periodontal Patient', in Newman, M. G. et al. (eds) Newman and Carranza's Clinical Periodontology. 13th edn. Los Angeles: Elsevier.

Fedi. (2005) Silabus Periodonti.

Rane, M. V. et al. (2017) 'Estimation and comparison of salivary calcium levels in healthy controls and patients with generalized gingivitis and chronic periodontitis', Journal of Oral Research and Review, 9, pp. 12-5. doi: 10.4103/jorr.jorr.

Sueishi, N. et al. (2017) 'Quantification of dental plaque in oral cavity was enabled by a novel algorithm of image processing', Journal of Oral Biosciences, 59(3), pp. 157-162. doi: 10.1016/j.job.2017.06.003.

Valm, A. M. (2019) 'The Structure of Dental Plaque Microbial Communities in the Transition from Health to Dental Caries 
and Periodontal Disease', Journal of Molecular Biology, 431(16), pp. 2957-2969. doi: 10.1016/j.jmb.2019.05.016.

Weijden, F. van der et al. (2015) 'Mechanical Supragingival Plaque Control', in Lang, N. P. and Lindhe, J. (eds) Clinical Periodontology and Implant Dentistry. 6th edn. Iowa: John Wiley \& Sons, Ltd., p. 677. 